\title{
Improving Critical Thinking in Academic Writing through Portfolio in Higher Education
}

\author{
D. K. Dewi \\ Department of Psychology \\ Faculty of Educational Science, State University of Surabaya \\ Doctoral Student of State University of Malang \\ damajantikusuma@unesa.ac.id
}

\begin{abstract}
Critical thinking skill is one of 21st century skills that supports the mastery of academic writing. Academic writing skill requires critical thinking to express arguments in such systematic and scientific way based on trusted sources. Facione (2011) argues that there are 6 stages in critical thinking, namely interpretation, analysis, interference, evaluation, explanation and self-regulation. These stages were applied to writing activities. The outline of academic writing consists of three parts, namely the introduction, development and conclusions. Each part requires the ability to think critically. To be able to think critically, one needs to have prior data. Therefore, it is necessary to use portfolio to support these strategies. This study uses action research to psychology students who programmed academic writing course.
\end{abstract}

Keywords-critical thinking, academic writing, portfolio, higher education

\section{INTRODUCTION}

Higher Education institutions around the world face the growing problem of relevance as they enter the twenty-first century. There is now growing list of skills employers are expecting of their employees, reflecting the changing world of work (Wallis in Hallissy). Students must learn the essential skills for success in today's world, such as critical thinking, problem solving, communication and collaboration (Trilling and Fadel, 2009).

Critical thinking is an important and necessary skill because it is required in the workplace, it can help you deal with mental and spiritual questions, and it can be used to evaluate people, policies, and institutions, thereby avoiding social problems (Hatcher and Spencer, 2005). Critical thinking is considered to be central to higher education or an essential goal of teaching (Kuhn, 1999), being the key objective of schooling (Scriven \& Paul, 2005).

Halpern (2003) proposes that the construct of critical thinking is a more meaningful way to conceptualize human intelligence, critical thinking is a process involved in any research activity (Phillips \& Bond, 2004).

Many researchers have asserted the influential role of critical thinking in students' academic achievement (e.g., Birjandi \& Bagherkazemi, 2010; Fahim, Bagherkazemi, \& Alemi, 2010). Critical thinking ability has been identified as one of the constructs which has been proven to be a good predictor of academic performance (Tsui, 1999).

Critical thinking is a skill like any other academic skill and can be developed over time, through a step-by-step process (Hatcher \& Spencer, 2005). Critical thinking is a skill that is also applicable to all academic levels and is necessary for academic preparation (Chaffee, 1992).

There are various ways to teach critical thinking. Theorists are divided into two camps regarding whether critical thinking is best taught as a general skill applied to all disciplines or as a skill used in a particular discipline (Al Sharadgah, 2014).

Dixon e.t. (2005) emphasize that writing is a vehicle through which students can express their critical thinking, and that writing seems to be an expression of critical thinking when students are trained to use critical thinking methods consistently in writing. Writers engage in a recursive process when writing and this process is regulated by distinct thinking processes that writers manipulate in their writing (Flower \& Hayes, 1981). Writing is a recursive process in that the student can return to a previous stage of the writing process while working on a later stage. In other words, while students were revising their essays, they may find themselves thinking of new ideas that could be included in the essay. This suggests that critical thinking and its skills may be enhanced in the process of students' writing.

From a style of evaluation in which students have to expose factual knowledge, there is a shift to ascertain what students are capable of doing with that knowledge across competencies; and tests are designed to measure what students know, rather than what students do not know. A formative evaluation makes the teacher and learner cooperate actively from the beginning to diagnose how correctly the process of learning is going in order to ensure good results. A continuous assessment then requires the use of different instruments for evaluation, so the traditional paper and pencil final exam is replaced or complemented by other instruments, such as portfolios and interviews (Martinez-Lirola \& Rubio, 2009)

A portfolio consists of a folder in which students keep several tasks to accomplish certain objectives and competencies selected by teachers; it may help students develop their written skills, as Celce Murcia and Olshtain (2000:159) indicate: "The portfolio, which is usually an ongoing collection of different writing assignments kept by the student in a folder or workbook, has become an important concept in developing writing skills and in giving teachers a fairer and more perceptive way to evaluate".

Portfolios can serve a critical role in helping students focus on expanding their minds through reading and discussion, clarifying their own thinking through writing, and broadening student's creative horizons (Bekurs and Santoli, 2004). Additionally, portfolio assessment allows the flexibility to monitor individual student progress while meeting community, state, and national standards. (Bekurs and Santoli, 2004). 


\section{LITERATURE REVIEW}

\section{A. Critical Thinking}

Wang (2009) defined critical thinking ability as the ability to think reasonably and reflectively. He further suggests that critical thinking is an ability that allows students to freely express their own ideas, to demonstrate the interrelationships among their ideas, and to generate higher levels of thinking, Dephi Research Project (Facione \& Facione, 1996) cited that critical thinking to be purposeful, self-regulatory judgment which results in interpretation, analysis, evaluation, and inference, as well as the explanation of the evidential, conceptual, methodological, criteriological, or contextual considerations upon which that judgment was based."

Paul and Elder (2006) interpret critical thinking as "thinking explicitly aimed at well-founded judgment, utilizing appropriate evaluative standards in an attempt to determine the true worth, merit or value of something". McPeck (1990) characterized critical thinking as the ability to suspend judgment, or temporarily suspend judgment, until sufficient evidence is accumulated to establish the validity of a proposition or action.

Facione (1990) who critical thinking as: "purposeful, selfregulatory judgment that results in interpretation, analysis, evaluation, and inference, as well as explanation of the evidential, conceptual, methodological, criteriological, or contextual considerations upon which that judgment is based."

Put briefly, critical thinking is an skill include 1) analyzing arguments, claims, or evidence (Facione, 1990; Halpern, 2003); 2) making inferences using inductive or deductive reasoning (Willingham, 2007); 3) judging or evaluating all aspects of arguments, cases, and situations (Lipman, 1988); 4) making decisions or solving problems (Ennis,1985; Halpern, 1998; Willingham, 2007); 5) interpreting and explaining (Facione, 1990); and 6) asking and answering questions for clarification (Ennis, 1985).

Facione (1990) said that critical thinking consists of five skills, interpretation, analysis, evaluation, inference, and explanation.

\section{B. Critical Thinking in Academic Writing}

Condon and Kelly-Riley (2004) said that "writing is a tool of thinking" marks the link between critical thinking and writing. Bean (2001) asserts that writing "requires analytical or argumentative thinking and is characterized by a controlling thesis or statement and a logical, hierarchical structure".

Sorrel et. (1997) clarify that writing requires one "[t]o connect ideas from internal and external sources, critically think about the ideas, and then infer a generalisation that gives the separate pieces of information a coherent verbal shape"

Schafersmen (1991) explains that "writing forces students to organize their thoughts, contemplate their topic, evaluate their data in a logical fashion, and present their conclusions in a persuasive manner". Good writing is therefore a reflection of good critical thinking. The sources of ideas can be from across a variety of texts and those based on observation, experience and reflection (Vardi, 1999).
Writing is an essential component in both developing and demonstrating critical-thinking skills, and has been called "the exterior sign of an interior thinking process" (Bean 1996). Elder and Paul (2006) point out the "intimate connection between the ability to write well and the ability to think well."

Critical thinking is also claimed to be important in the acquisition of language skills particularly writing and reading (Freire, 2007), two indispensable language skills that can help undergraduates secure their academic success. However, studies on the relationship between critical thinking and these two language skills, especially those which use second language learners as the sample are still not sufficient. Similarly, there are not many studies conducted on the relationship of the aforementioned construct with general language proficiency.

Academic writing is always a form of evaluation that asks you to demonstrate knowledge and show proficiency with certain disciplinary skills of thinking, interpreting, and presenting. Writing the paper is never "just" the writing part (Irvin, 2010)

Olson (1992) argues that thinking can be refined through pre-writing, writing, revising and editing activities. This means, as a writer is engaged in the writing process, the writer is using his/her judgments to evaluate his/her own text and make any necessary changes to express his/her ideas clearly and confidently to readers. Thus, engaging students in critical thinking during [academic] writing classes is very important but it can only be achieved if the writing assignments foster such work (Reynolds \& Moskovitz, 2008).

Hence, critical thinking in academic writing is a manifestation of a writer ability to understand and analyses the ideas, evaluate and synthesize the arguments in a variety of sources before making any conclusions, and then presenting them clearly to an audience. It entails the ability to: understand key concepts and ideas; distinguish the main ideas and arguments from the subordinate ones; judge their relevance and provide reasons; judge the credibility of sources of information; and be able to paraphrase them and later draw conclusions based on all the justifications made. Engaging oneself in all these tasks exercises thinking and heightens it.

Critical thinking is important and applicable to so many areas of life and learning. It has been said that when people are not able to think critically and intelligently about the myriad of issues and problems that confront them, they then may come across many answers, and still do not know what the answers mean (Halpern, 1998). Walker (2003) suggests that in order to promote critical thinking in learners, teachers should teach them some strategies. He claims that learners should be encouraged to be inquisitive, ask questions, and not believe and accept everything they are told. Two other strategies suggested by Walker (2003) are classroom discussion and debates and written assignments. He further claims that thinking develops with practice and evaluation over time by using multiple strategies.

Critical thinking also seems to play a role in language teaching and learning. Williams and Burden (1997) claim that 
learners need to use their minds to observe, think, categorize and hypothesis in order to work out how a language operates.

\section{Portfolio}

Writing is a process, not a product-oriented task, and expressive writing (i.e., exploratory writing) is a form of communication closest to that of speech. "Exploratory writing takes practice, it is a powerful tool for focusing the mind on a problem and stimulating thought" (Bean, 1996)

Expressive writing creates comfort and confidence in the mind of the student. Through creating new writing habits, the student overcomes the fear of writing and possibilities for creativity and growth open up.

Assessment in education plays an important role in tying instruction to learning to meet certain educational goals specified by education administrators and policy makers, and to satisfy the demand of stakeholders that include students, parents, communities and employers. Assessment works best when its purpose is clear, and when it is carefully designed to fit that purpose.

The three main groups of purposes of assessment are to assess for learning, to assess as learning and to assess of learning (Earl et al., 2006). The three are inter-related with assessment of learning more easily distinguished from assessment for and as learning.

Assessment of learning aims to check students ${ }^{\text {ee }}$ learning, usually at the end of a course, and is summative in nature. It summaries what students are able to do and what they know in comparison with the expected learning outcomes specified in the curriculum or how students achieve in relation to other students (Earl et al., 2006). The results of assessments may be accessible for public view "as evidence of achievement to parents, other educators, the students themselves, and sometimes outside groups (e.g. prospective employers and other educational institutions)" (Earl et al., 2006, p. 55).

In contrast, assessment for learning serves to promote learning as it progresses via the feedback gathered from the assessments. It is formative assessment. Assessment for learning is more than just ongoing assessments of students ${ }^{\text {ee }}$ progress. It also includes how students can benefit from the feedback to help them to further improve in learning (Black and Wiliam, 1998; The Assessment Reform Group, 1999; Chappuis, Stiggins, Arter \& Chappuis, 2003; Stiggins et al., 2004). Effective assessment for learning requires high quality interactions between teachers and students, and between students and peers (Learning and Teaching Scotland, 2007). Being made aware of their responsibility to make progress, students can monitor their learning by evaluating the feedback gained from their teacher and peers.

Portfolio assessment places limited boundaries on the role of writing in students' lives and empowers them to take chard of their own learning.

Administering portfolio assessment can be as simple or as complicated as the teacher, students, and circumstances dictate. In brief, students keep their writings, and as time progresses, they select pieces to revise. Teachers hold writing conferences with students to aid them in revision strategies. At the conclusion of a given time period (e.g., an instructional unit, a quarter, or a semester), students and teacher formulate criteria for evaluation, and students assemble and submit either the entire portfolio or selected revisions.

Bratcher (1994) emphasizes that "grading" is defined as "communication between teacher and student that is designed to enhance the student's writing". Clear standards for evaluation of finished pieces need to be established so that communication is clear about the merits and demerits of student writing in the eyes of the teacher.

Portfolio assessment is appropriate for meeting these fundamental objectives of stimulating cognitive development, inspiring creativity, and promoting student responsibility. De Fina (1992) outlines several student-centered objectives of portfolio assessment: to examine growth over time, to develop a sense of process, to creative a means of self-evaluation, to determine individual goals, to empower confidence as developing writers, to be presented with real-life learning opportunities, and to observe language development.

\section{METHOD}

\section{A. Participants}

Participants of the study were 41 students from the Department of Educational Management at State University of Surabaya, during the third semester of the academic year 2013/2014. Participants' ages varied, but all of them were adult learners with the mean age being nearly 19 . Gender was not considered as a moderator variable.

\section{B. Procedure}

First, the researcher explained the program to the participants. The instructor taught the class, using critical thinking in academic writing steps.

\section{TABLE I. CRITICAL THINKING IN ACADEMIC WRITING STEPS}

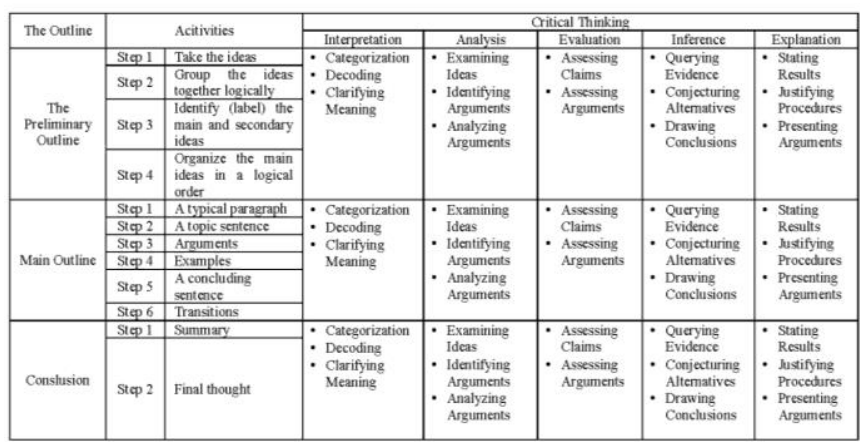

The researcher checked the assignments and gave the comments back to the students. Each writing task was carried out in three sequential stages, the preliminary outline, main outline and conclusion. These stages were the followings:

- The Preliminary Outline

The participants were required to research the topic. In the first session, participants were asked to browse the web page containing the critical thinking skills lessons where 
they worked independently to study the lesson set for the task of writing and thus learning critical thinking skills. Then, participant were asked to write the text.

- The Main Outline

Were encouraged to read a sample model on the topic they were to write about. Then, participants were asked to organize the information and ideas they had generated in the pre-writing stage and to put them in an essay applying the critical thinking skills they had learned.

- The Conclusion

The participants shared their first drafts with other peers this stage allowed time to reflect upon what had been written to rethink, re-see, and reshape words and ideas. Participants received comments, discussed them further with peers and decided what to incorporate in their final drafts.

\section{FINDINGS}

The research there are three major findings that will be discussed in this section include:

- Increase in the participants' self-knowledge after portfolio development; participants' perspectives on their educational lives changed after developing a portfolio, they expressed: a new sense of self-discovery and personal empowerment to achieve future goals.

- Improved appreciation of the role of reflection in recognizing learning; participants confirmed the acquisition of better organizational skills as a consequence of portfolio development. The portfolio process helped them understand how their learning took place due to the need to critically analyze, organize, evaluate, and write about their learning from experiences

\section{REFERENCES}

[1] Hallissy, M., Butler, D., Hurley, J., \& Marshall, Kevin. Redesigning Education. Meeting the Challenges of the $21^{\text {st }}$ Century.

[2] Trilling, Bernie \& Fadel, Charles. (2009). 21 $1^{\text {st }}$ Century Skills. Learning for Life in Our Times. California, Jossey-Bass. Retrieved from https://yasamboyuogrenme.wikispaces.com

[3] Hatcher, D. L., \& Spencer, L. A. (2005). Reasoning and Writing: From Critical Thinking to Composition (3rd. ed). Boston: American Press.

[4] Kuhn, D. (1999). A developmental model of critical thinking. Educational Researcher, 28 (2), 16-26. Retrieved from http://www.pop.educationforthinking.org/sites/default/files/pageimage/1 -01DevelopmentalModelCriticalThinking.pdf

[5] Scriven, M., \& Paul, R. (2005). Defining critical thinking. Retrieved from http://www.criticalthinking.org/aboutCT/definingCT.cfm

[6] Halpern, D. F. (2003). Thought and knowledge: An introduction to critical thinking (4th ed.). Mahwah, New Jersey: Lawrence Erlbaum Associates. Retrieved from www.libgen.net

[7] Phillips, V., \& Bond, C. (2004). Undergraduates experiences of critical thinking". Higher Education Research and Development, 23 (4),277294. Retrieved from http://www.tandfonline.com/ doi/abs/10.1080/ 0729436042000235409

[8] Birjandi, Parviz \& Bagherkazemi, Marzieh. (2010). The Relationship between Iranian EFL Teacher' Critical Thinking Ability and Their Professional Success. English Language Teaching, 3(2), 135-145. Retrieved from http://www.ccsenet.org/jounl/index.php/elt/article
[9] Fahim, M., Bagherkazemi, M., \& Alemi, M. (2010). The Relationship between Test Takers' Critical Thinking Ability and Their Performance on the Reading Section of TOEFL. Journal of Language Teaching and Research, 1(6), 830-837. Retrieved from www.academia.edu/277611

[10] Tsui, Lisa. (1999). Courses and Instruction Affecting Critical Thinking. Research in Higher Education, 40(2), 195-202. Retrieved from link.springer.com/article

[11] Chaffe, John. (1994) Thinking Critically (4 ${ }^{\text {th }}$ Edition). Book Reviews/Comptes Rendus. Boston, Houghton Mifflin

[12] Al Sharadgah, Talha Abdullah. (2014). Developing Critical Thinking Skills through Writing in an Internet-Based Environment. International Journal of Humanities and Social Science, 4 (1), 69-178. Retrieved from www.ijhssnet.com/journal/index/2237

[13] Flower, Linda \& Hayes, John R. (1981). A Cognitive Process Theory of Writing. College Composition and Communication, 32(4), 365-387. Retrieved from http://kdevries.net/teaching/teaching/wpcontent/uploads/2009/01/flower-hayes-81.pdf

[14] Martinez-Lirola, Maria \& Rubio, Fenando. (2009). Students' Beliefs about Portfolio Evaluation and Its Influence on Their Learning Outcomes to Develop EFL in a Spanish Context. International Journal of English Studies, 9(1), 91-111. Retrieved from http://www.uhu.es/fernando rubio/universidad/INVESTIGACION/my publications to download_archivos/2009\%20IJES

[15] Celce Murcia, M. \& Olshtain, E. (2000). Discourse and Context in Language Teaching - A Guide for language Teachers. Cambridge: Cambridge University Press. Retrieved from http://www.cambridge.org/download_file/625124/0/.

[16] Bekurs, Diane \& Santoli, Susan. (2004). Writing is Power: Critical Thinking, Creative Thinking and Portfolio Assessment. Retrieved from http://www.usca.edu/essays/vol102004/santoli.pdf

[17] Wang, Y. H. (2009). Incorporating critical thinking skills into an English conversation program. European Journal of Social Sciences, 11(1), 5160.

[18] Facione, Noreen C \& Facione, Peter A. (1996). Externalizing the Critical Thinking in Knowledge Development and Clinical Judgment. California Santa Clara University. Retrieved from http://www.insightassessment.com

[19] McPeck, H. (1990). Teaching critical thinking: Dialogue and dialectic. New York: Routledge.

[20] Facione, Peter A. (1990). Critical Thinking: A Statement of Expert Consensus for Purposes of Educational Assessment and Instruction. Executive Summary The Delphi Report. Retrieved from https://assessment.trinity.duke.edu/documents/Delphi_Report.pdf

[21] Willingham, D., T. (2007). Critical thinking: Why is it so hard to teach? American Educator, 27, 8-19.

[22] Lipman, M. (1988). Critical thinking: What can it be? Educational Leadership, 46(1), 38-43.

[23] Ennis, R. H. (1985). A logical basis for measuring critical thinking skills. Educational Leadership, 43(2), 44-48.

[24] Condon, William \& Kelly-Riley, Diane. 2004. Assessing and Teaching What We Value: The Relationship between College-Level Writing and Critical Thinking Abilities. Assessing Writing, 9,56-75. doi:10.1016/j.asw.2004.01.003 Retrieved from www.sciencedirect.

[25] Irvin, L. Lennie. (2010). What Is Academic Writing?. Retrieved from http://www.parlorpress.com/pdf/irvin--what-is-academic-writing.pdf

[26] Sorrell, J.M., Brown, H.N., Silva, M.C., \& Kohlenberg, E.M. (1997). Use of writing portfolio for interdisciplinary assessment of critical thinking ou Nursing Forum, 32(4), 12-24.

[27] Dixon, F., Cassady, J., Cross, T., \& Williams, D. (2005). Effects of Technology on Critical Thinking and Essay Writing among Gifted Adolescents. Prufrock Journal, 16(4), 180-189. Retrieved from http://files.eric.ed.gov/fulltext/EJ746041.pdf

[28] Schafersmen, S. D. (1991). An introduction to critical thinking. Retrieved March 31, 2009, from http://smartcollegeplanning.org/wpcontent/uploads/2010/03/Critical-Thinking.pdf

[29] Vardi, Iris. 1999. Developing Critical Writers at the undergraduate level: some insights from critical thinking pedagogy and linguistics. Retrieved from http://webcache.googleusercontent.com. 
[30] Bean, J. (2001). Engaging ideas: The professor"s guide to integrating writing, critical thinking, and active learning in the classroom. San Francisco: Jossey-Bass.

[31] Bratcher, S. (1994). Evaluating children's writing: A handbook of communication choices for classroom teachers. New York: St. Martin's Press.

[32] De Fina, A.(1992). Portfolio assessment: Getting started. New York: Scholastic.

[33] Olson, C. B. (1992). Thinking writing: Fostering critical thinking through writing. New York: Harper Collins Publishers.

[34] Reynolds, J., \& Moskovvitz, C. (2008). Calibrated peer review assignments in science courses: Are they designed to promote critical thinking? Journal of College Science Teaching, 38(2), 60-66.

[35] Facione, P. (1998). Critical Thinking: What It Is and What It Counts. California, California Academic Press. Retrieved from http://spu.edu/depts/health-sciences/grad/documents/CTbyFacione.pdf

[36] Jones, A. (2004). Teaching critical thinking: An investigation of a task in introductory macroeconomics. Higher Education Research \& Development, 23(2), 167-181. Retrieved from http://www.tandfonline.com/doi/abs/10.1080/0729436042000206645

[37] Center for Critical Thinking (2004). Retrieved June 5, 2011 from http://www.criticalthinking.org/starting/Begin-CTModel.cfm

[38] Ennis, R. (1993). Critical Thinking Assessment. Theory into Practice, 32(3), 1-8. Retrieved from http://www3.qcc.cuny.edu.

[39] University of Ottawa. Academic Writing Help Centre. 2008, pp.1-2

[40] Stroupe, Robert R. (2006). Integrating Critical Thinking Throughout ESL Curricula. TESL Reporter, 39, 42-61. Retrieved from https://ojs.lib.byu.edu/spc/index.php/TESL/article/download/32504/306 79 . 